the low blood glucose levels frequently seen in newborn babies. These babies seldom show clinical signs of hypoglycaemia, possibly because, as in fasting adult man, ketone bodies may be an important cerebral fuel in neonates. Some babies, however, particularly those thought to have been malnourished in utero, may develop clinical signs of hypoglycaemia which must be treated with intravenous glucose and possibly hormoncs to avoid permanent brain damage or death.

On the second day-with Dr Widdowson in the chair - Dr E. Hunt and Dr D. Hull discussed nutrition and thermoregulation in the newly born pig and baby, and showed how both species have to raise their rate of metabolism during the first day after birth in order to maintain their body temperature. The pig uses carbohydrate, and the human baby uses fat as the food reserve to provide energy for metabolic purposes immediately after birth.

\section{Developing Agriculture}

THe vital importance of combating plant pests and diseases in the developing countries was one of the first points to emerge at the first International Congress of Plant Pathology, which began at Imperial College last Sunday and continues until July 26. In the opening address Professor P. M. S. Blackett, president of the Royal Society, told the delegates-there are more than 1,300 of them from at least sixty countries-how much the developing countries depend on a prosperous agriculture. But he said: "Science is no magic wand to wave over a poor country to make it a rich one".

With independence, the governments of many countries inherited an agricultural system which had been run by scientists from the ruling country, many of whom returned home quickly in the ensuing wave of nationalistic feelings. They did not leave behind trained personncl to take their places, and many projects were abandoned because there was nobody to continue them. Dr Margaret Keay, speaking during the first session of the congress about educational problems in developing countries, said that there is an inequitable distribution of plant pathologists in the world. Dr W. Carter, talking about problems facing plant pathologists in the field, quoted the case of Jamaica, where yellowing disease of coconut palms has wiped out commercial plantations in many areas. Yet Jamaica has only one plant pathologist in its department of botany. In the developing countries there is too much research to be done by too few people, many of whom, coming from countries with different crops, soil and climate, are slow to appreciate the problems they are faced with.

One of the problems in the universities is that unsuitable courses, which concentrate on the taxonomic aspect of the causative organisms, have persisted from the days when they were initiated by teachers from the developed countries. Professor M. A. Nour of the University of Khartoum said that in countries where plant pathology is such an urgent problem, the emphasis should be on producing general practitioners of erop protection. At Khartoum there is a department of crop protection where all aspects of plant diseases are studied, with the emphasis on control. Such courses need to be adopted as quickly as possible by the universities where the taxonomic approach and the separation of botany and zoology persist.

\section{Parliament in Britain}

\section{Sea Bed}

$$
\text { by our Parliamentary Correspondent }
$$

Mr Goronwy RoBerts said that the Government is actively considering its policy towards the exploitation of the sea bed, and national rights over it. Mr Tom Dalyell said that, if there was to be an adequate flow of capital and investment, certain urgent problems of international law needed to be solved. Mr Roberts agreed, and said that these, together with technicel problems, were to be the subject of an ad hoc committes set up by the United Nations. Mr Hugh Fraser suggested that before the Government could adopt 2 sensible position internationally it would have to set its own national programmes in order. So far, he claimed, there had been nothing but the vaporous outpourings of the Ministry of 'Technology. Mr Roberts denied this; the matter, he said, was adequately taken care of. (Oral answer, July 8.)

\section{Food Irradiation}

Mr Gerry Fowlen, for the Ministry of Technology, seemed unenthusiastic about the prospects for preservation of fish by irradiation. The commercial prospects seemed small, and there was concern about possible health hazards. There would be no official representation at trials which were to take place in Iceland. (Written answer, July 8.)

\section{Hospital III-treatment}

The Minister of Health, Mr Kenneth Robinson, gave the results of the committees of inquiry into allegations of ill-treatment at geriatric hospitals. Most of the allegations had been found to be "totally unfounded or grossly exaggerated". The committees had in general reported favourably on the conditions in hospitals, although some suggestions for improvements had been made. One or two incidents of ill-treatment had been found. The findings and recommendations of the committees were being published as a White Paper. (Report of committee of inquiry, July 9.)

\section{Sonic Booms}

The Minister of Technology, Mr Anthony Wedgwood Benn, revealed that just over $£ 4,000$ has been paid in compensation for damage caused by the sonic boom tests carried out in 1967 . Of this, $£ 3,200$ had been paid out in the London area, $\mathfrak{f 7 0 0}$ in the Bristol Channel area, and the rest in Dorset. Mr Benn made no comment on the implications of this decision, but said that he would report on the tests soon. (Written answer, July 11.)

\section{Power Station Orders}

Mr Emanuel Shinwell and Mr Eric Lubbock asked when the Central Electricity Generating Board would be allowed to place orders for new generating stations, at Seaton Carew and Heysham. Mr Roy Mason, the now Minister of Power, said that no decision had yet been reached, but the timing of orders would depend on the outcome of the present capital investment reviews. Mr Lubbock pointed out that the electrical manufacturing industry had not had an order for sixteen months. $\mathrm{Mr}$ Leadbitter said that there had been nothing but one excuse after another for the past, two years; first it was the load estimates, now the capital estimates. Mr Mason could only say that the Central Electricity Generating Board programme would be decided before the autumn, and the matter could then be cleared up. (Oral answer, July 9.) 